Deane's concept (zonal theory). But with prolonged injection of large amounts of AĆTH, thè sudanophilic granules of the zona glomerulosa were also depleted, and the glomerulosa cells were also hypertrophied. From this experimental result and our other observations, the author made the following conclusions. During overwhelming cortical hypersecretion, the demand for fascicular function is increased and the cells of the zona glomerulosa are transformed into fasciculata cells. Therefore the zona glomerulosa and the zona fasciculata have the same cells of origin, and are not independent cells.

Chapter 3. Morphological changes of the adrenal cortex under various stressfull conditions.

The histological and histochemical changes of the adrenal cortex under stress generally seemed to be non-specific reactions and similar to the reaction following ACTH injection. But some of the stressors caused peculiar changes in the adrenal cortex. After prolonged administration of adrenalin, many exhaustive vacuoles were seen in the zona fasciculata. Vacuolated changes in the cells of the zona glomerulosa were observed following formalin injection. After unilateral adrenalectomy or prolonged injection of insulin, the zona glomerulosa showed evidence of hypertrophy and hyperplasia. These specific reactions to stress, especially the changes in the zona glomerulosa, suggested a direct specific effect of the stressor.

Chapter 4. The influence of various steroid hormones on adrenocortical function.

Some of the steroid hormones exerted specific effect on the adrenal cortex. Testoids, especially caused specific changes in the adrenal cortex. Testoids generally depress adrenocortical function, but in hypophysectomized rats, testoids conversely inhibit the shrinkage of the adrenal cortex. Testoids also decreased the sudanophilic granules in the adrenal cortex of normal and hypophysectomized rats. Testoids, especially MAD, bring about fatty metaplasia in the adrenal cortex and this change could be observed in both intact and hypophysectomized rats.

Estrogens, cause hypertrophy of the adrenal cortex, but this effect is through the anterior pituitary ACTH secretion. Large amounts of progesterone produced fatty metaplasia of the adrenal cortex, but this change was not observed in hypophysectomized rats.

Cortisone induced cortical atrophy, through pituitary ACTH depression. The sudanophilic granules in the zona fasciculata and the reticularis were almost completely depleted by cortisone. DOCA caused atrophy of the zona glomerulosa directly and not through pituitary depression.

\title{
Studies on the Nature of Staub-Effect of Blood Sugar Curve following the Administration of Glucose
}

\author{
By
}

\author{
Mizuto KAJIYAMA \\ Second Division of Internal Medicine, Kobe Medical College \\ (Director: Prof. M. Takeda)
}

For the clucidation of Staub-Efrect (S-E) on the course of blood sugar following the double administrations of glucose, it would be most essential to have informations with regard to the following items:

1. The amounts of uptaken and deposited carbohydrate in the liver and in the other tissues (the muscle and skin) after the glucose injections. The comparison of the total amount of carbohydrate deposited with the first and second portions of glucose injections should there be made.

Vol. 31 No. 10 
2. The amounts of excreted sugar into the urine during the tolerance tests. The estimations of the carbohydrate figures of the liver and the tissues (by the method of Yamamoto), or the urine sugar after the glucose injections were carried out with the normal (S-E positive), phosphor- (S-E markedly negative), or alloxan-pəis oned (S-E indeñaite) rabbits. From the determination of the total amount of carbohydrate in the liver and tissues before and after one hour (or two hours) of glucose injection, we are able to know the amount of deposited carbohydrate in the liver and tissues. The results are as follows:

(1) The total amount of deposited carbohydrate in the normal liver was markedly increased after the injection of sugar, and in the second portion this was significantly higher than in the first.

In the phosphor- and alloxan-rabbits, however, there were marked decrease of the total carbohydrate deposit, especially following the second portion.

(2) The uptake and the deposition of sugar in the muscle and skin following the injection of glucose were very small, compared with the liver.

The total amounts of deposited carbohydrate in the muscle and skin in the case of normal or alloxan-rabbits after the second portion of sugar injection were found to be moderately increased, while the phosphor-rabbit showed a better deposition in the first in jection than in the second.

(3) From these findings, it is evident than in the case of normal animal the S-E was positive, while in the case of phosphor-rabbit strongly negative.

(4) From the uptake and the deposition of injected sugar in the liver, we may expect in the alloxan rabbit a marked negative S-E after the glucose injection, like that we have seen in the phosphoranimal, but in the fact the positive or slightly negative S-E figure in the case of alloxan rabbit was found.

As the reason for this descrepancy we may assume that the highly excretion of urine sugar after the glucose injection in the alloxan rabbit, especially in the second portion of sugar injection, may inhibit the blood sugar curve in the second portion of glucose injection (in the alloxan rabbit the double amounts of sugar was excreted into the urine, compared with the case of phosphor rabbit). Moreover, in the case of alloxan rabbit, the increased deposition by second portion of in jected glucose in the muscle and skin may affect to lower the blood sugar curve.

(5) Based upon these results as described above, we may suggest on the nature of S-E effect on the blood sugar curve following the glucose injection in two divided portions, firstly that the increased amounts of total carbohydrate deposit of liver by the second portion of sugar injection is most essential, secondly that the high excretion of urine sugar, especially after the second portion of sugar injection, and the increased amount of carbohydrate deposition in the muscle and skin after the second portion of glucose injection would act inhibitory on the rise of blood sugar curve after the second portion of sugar in jection. 


\title{
糖負荷試驗血糖曲線上に見られる Staub-Effekt の 本態に関する実験的研究
}

\author{
神戸底科大学第二内科学教室（指䆃 竹田正次教授） \\ 梶山瑞 人
}

\section{I。緒霅}

糖二重負荷試験血糖曲線上に見られる Staub-Effekt (S-Eと略す) は Hamman \& Hirshman (1919)1) Staub $\left.(1921)^{22}\right)$ 及び Traugott $\left(19223^{3)}\right.$ 亿よつて見出され，臨床上糖求病の診断並びに予後判定上重要な役目を果 して居るが，本現象の本態に関する研究は其後多数の学者によつてせられたのに拘らず未だ解明せられて居 ない.

健常人若くは常動物で反覆糖投与の場合, 次回糖投与後の血糖高峰が初回のそれに比し低值 ( $\mathrm{S}-\mathrm{E}$ 陽性) であるのは糖負荷により刺㦸せられた膵う氏島の機能旺盛に因る結果であると説明する学派 (Staub)；Depisch \& Hasenöhrl ${ }^{(5) 6)}$;Adlerscberg \& Porges ${ }^{(1)}$; Nielsen \& Lewis ${ }^{8)}$; Jordan ${ }^{9)}$; Kohn, Fries \& Felshin ${ }^{10)} ;$ Devel \& Gulick ${ }^{11)}$; Holt \& Greisheimer ${ }^{12)}$; Cori ${ }^{13)}$; Williams \& Dick ${ }^{17)}$ ) と肝加らの糖放出条件如何によると張主する

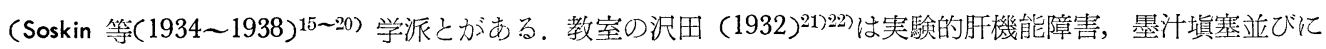
饑餓家鬼に就いて S - E 現象索観察した結果, 肝機能障害家鬼では S-Eカ㵔明陰性を発現するが，肝糖原量 之は直接の関係が無いと報じ, 更化各種糖頪中葡萄糖, 果糖, マンノ一ゼは健常動物に於て $\mathrm{S}-\mathrm{E}$ 陽性発現 物質であるが，ガラクトーゼ，麦芽糖及び孚糖によつては S-E 陽性を見ないと報ジた.

本教室で浪従来生体内に於ける注射糖の運命特々注射糖の臟器(肝)，組織(笳，皮膚)亿於ける游離糖，糖 原及び水解糖への復元並びに移転化関係就いて, 正常家鬼 (乗金 ${ }^{23)}$ ), 燐中毒 $\left(\right.$ 新海 ${ }^{24)}$, 中野 ${ }^{25}$ ) )及びア口 キサン家鬼 (中野勇) を使用して, 実験的䎲研究を行つて来たが，それら一連の研究結果並びに最近の文献 に徵して注射糖の運命を考察すると，

(a) 注射糖は主部分は肝, 一部は他組織（筋，皮膚）に一旦収容せられる。

（b）臟器，組織に収容せられた糖は当該臟器，組織で蔵蓄せられる（韵糖の型体は遊離糖，糖原，水解 糖である.

（c）大量桾静注若くは病的の場合には餐から排泄せられる。

(d) 注射糖の一部は分解せられ，焦性葡萄酸方域に於て中間並びそ終末産物一移行し或は脂質入転化也 られる。

（e）血中に遊睢糖として停滞する。

今 $\mathrm{S}-\mathrm{E} の$ 木態即ち次回注射糖に於ける血糖最高峰が初回のそれに比して高度である病的の場合 ( $\mathrm{S}-\mathrm{E}$ 陰 州: 亿就小て考察して見ると，

(a) 次回注射糖の藏器，組織に於ける仪“谷能が初回の之れよりも不良な場合.

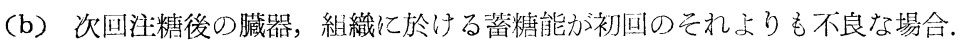

(c) 次回注糖後化於ける糖の分解力湔回注糖後上りも不良な場合.

(d) 次回注糖後の尿糖排泄力初回のそれよりも小である場合.

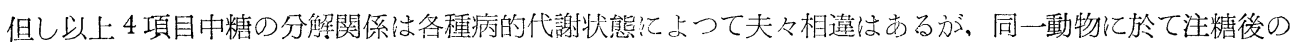

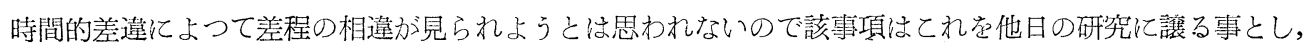

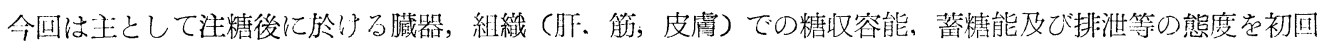

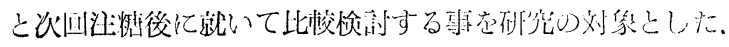




\section{II. 実 驗 方 法}

実験動物には $2 \mathrm{~kg}$ 内外の白色家鬼赏用い，燐中毒家鬼としては「猫いらず」の $10 \mathrm{mg} / \mathrm{kg}$ をオブラートの 小片に包んで 1 日 1 回宛 1 ～ 2 日間経口投与した家鬼を，又アロキサン糖尿家鬼としては「ア」 $150 \mathrm{mg} / \mathrm{kg}$ を $5 \%$ 水溶液として静注，持続性高血糖並びに糖尿を起した事を確めてから実験䎲供した。

実験前 12 時間は家鬼慨から離し，実験当日は早朝略々一定時間に $10 \%$ 葡萄糖液 $15 \mathrm{cc}$ 宛 $1 \sim 2$ 時間の間隔 で 2 回,一側の耳静脈㲸静注し，其間一定時間間隔及び楉液注射前に反対側つ耳静脈より採血して HagedornJensen 法》で血糖量を測定し，同時行糖液注射前及び注射後们肝，筋及び皮膚の中一種類の藏器又は組織片

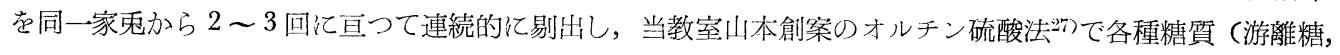
水解糖及び糖原】量を測定し，尚糖液注射直前六ラトンカテーテルて採尿，膀胱を空虚に1，其後持続力 テーテルで初回糖投与後より次回糖投与直前迄及び次回梼投与後実験終了迄の雨部分尿を採取し，前尿は捨 て，糖液注射後の両部分尿仁就いて Pavy-隈川一須藤法28;て還元值を測つて之を尿糖量とした。

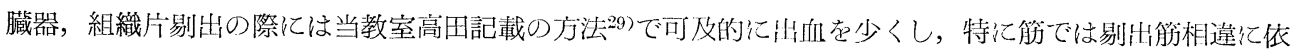
る誤差を避けるために一定の筋から試料を剔出した。

\section{III. 実 験 成 績}

\section{[I] 正常並びに病的家鬼に於ける糖負荷血糖曲線の検討 (図 1, 2,3,4)}

図 1，2，3，4で見られる様々，同量の糖を前後 2 回静注したとしても其糖静注の時間的間隔を相違せし

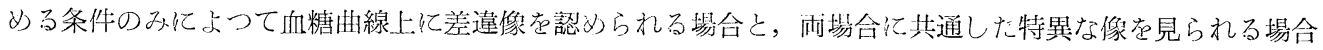
とがある。

第 1 図 $10 \%$ 藏萄精液 $15 \mathrm{cc}$ 宛 2 回静注家鬼 (正常, 燐中素,「ア栯尿) 血楉曲線 (精負荷間隔 2 㭙間(各3例平均值))

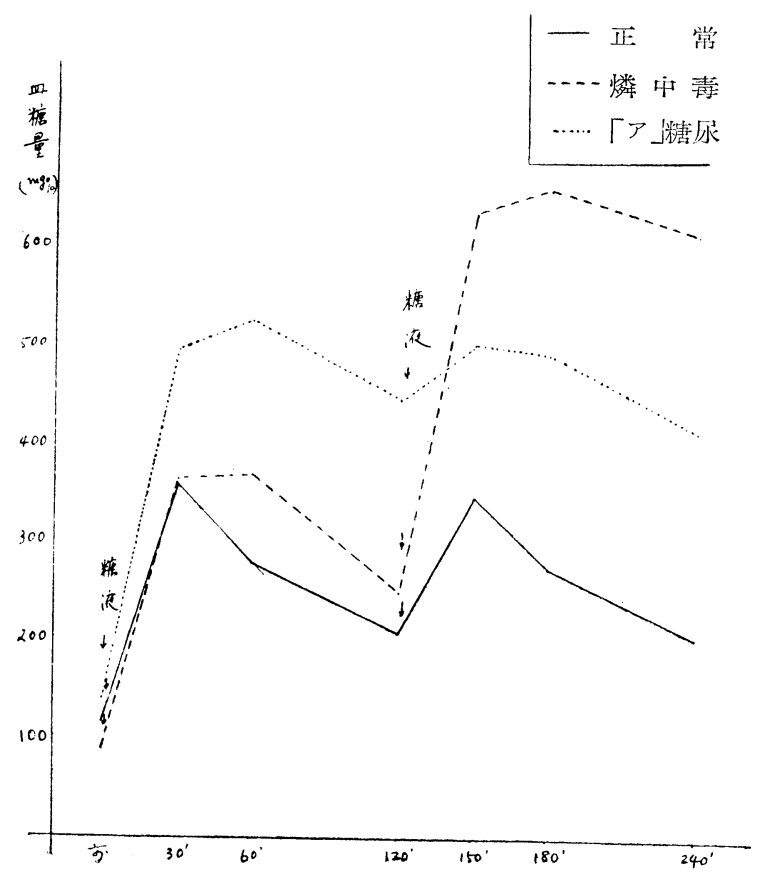

管 2 図 $10 \%$ 䈻葡糖液 $15 \mathrm{cc}$ 宛 2 回静注家身( 正常,

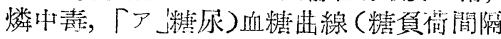
1 時間) (谷 $7,6,8$ 例平均值)

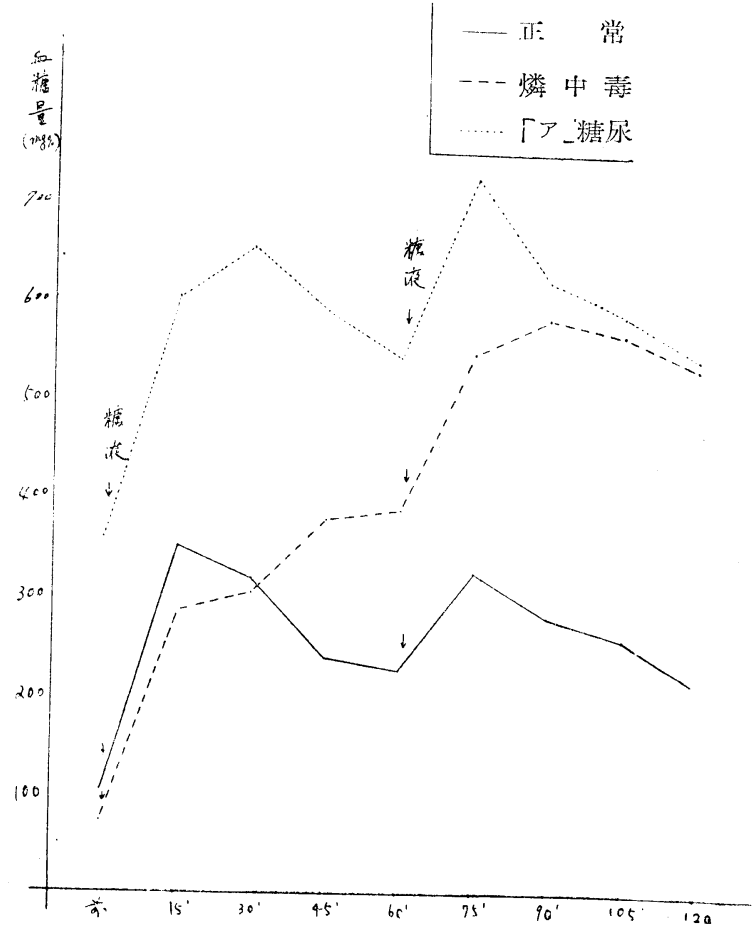

第31卷 第10躆 
第了図 糖注射後冬時期に於行万占糖量柏互の

比較 (糖泩射間隔 2 時椚)

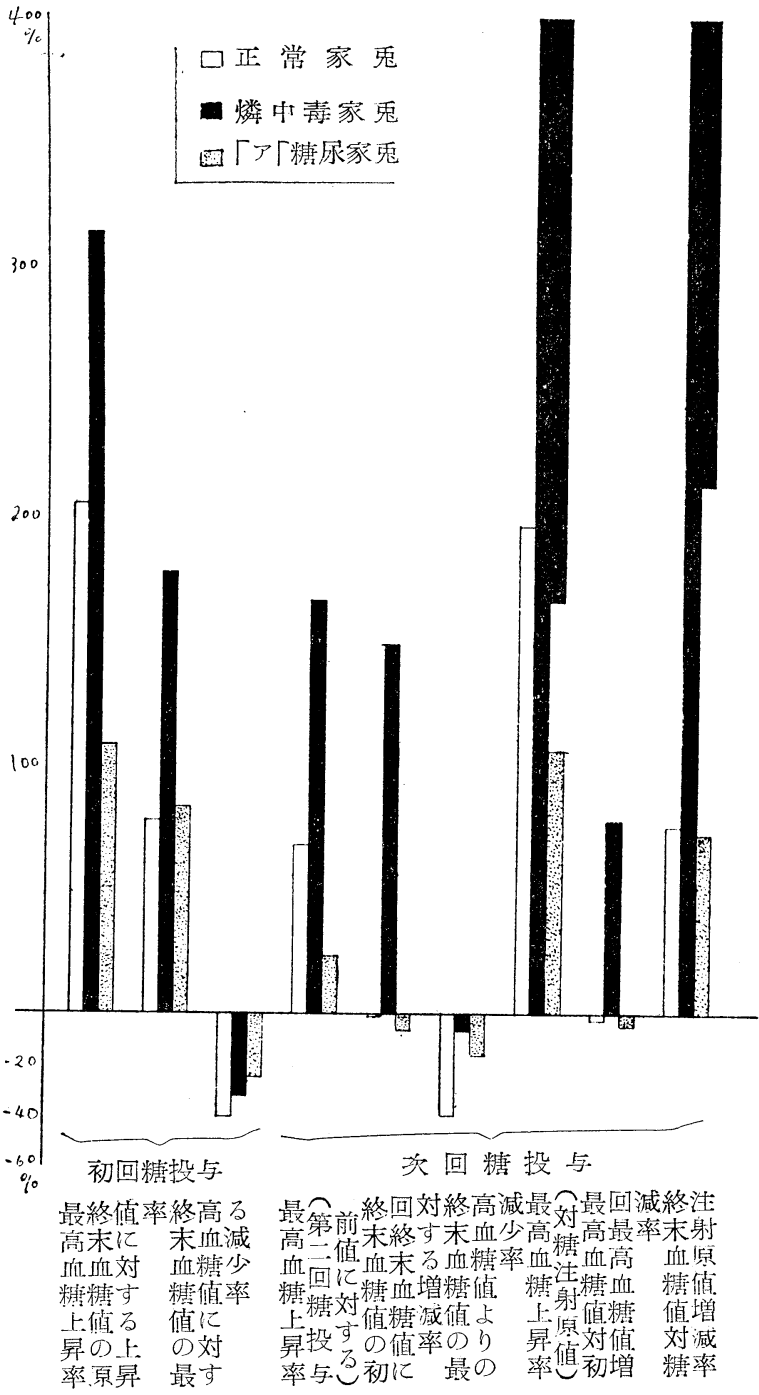

(a) 糖静注前の血糖値は燐中毒家鬼では低血糖,「ア」家鬼では高血糖である.

（b）初回糖静注後の血糖最高峰到達時間は3 種家鬼に於て夫々相違をして居る. 即ち正常家鬼では最も 早く(注射直後), 燐中毒家鬼で最も遅く，「ア」糖尿家鬼では其中間である。然るに次回注糖後の血糖最高 峰到達時間は正常及び燐中毒家鬼では初回と同様の所見であるが，「ア」家鬼では正常と同様注糖直後に最 高峰を示す.

（c）注射前血糖值に対する最高血糖上昇率は，初回及び次回注糖の両場合共に燐家鬼で最大，次に正常 家鬼か位し，「ア」家鬼內゙最小である。

注糖時間の間隔を短縮せしめた条件下では (每 1 時間注糖), 次回注糖後に於け乃血糖最高峰の再注糖前 值に対する上昇率は 3 種家鬼共て著小である。乙れは注糖時間間隔短縮の場合には初回終末時の血糖位低下 が不充分で比較的高位にある為々因る結果と考えられる。特に燐家鬼では注糖後 1 時間では未だ血糖曲線住 
第 4 図 糖洼射後备時期に於け弓血糖量相互の 比较 (糖注射間䧈 1 時間)

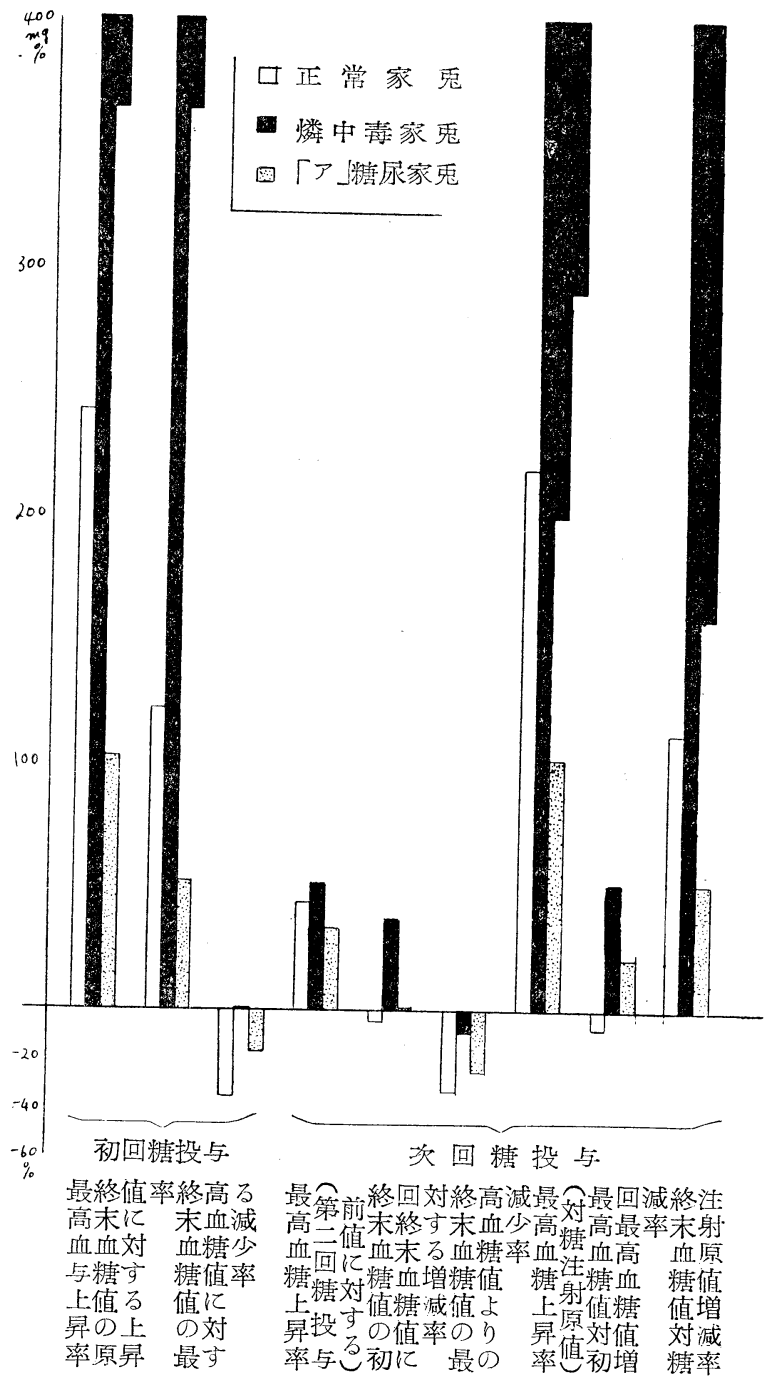

下降曲線に移らずして上昇曲線の途次沉ある.

(d) 注糖終末血糖值の夫々の注糖前值に対する上昇率は初回及び次回注糖の場合共亿燐獣で最大，健常 と「ア」家鬼間には大差索認めない。

然るに注糖時間間隔を短縮（每I 時間注糖）した場合には，次回注糖の場合に於ける注糖前值対終未血糖 值上昇率は毎 2 時間注糖の場合て比して稍々著しく減少する。乙れも注糖時間間隔短縮の場合は初回注糖の 際の終末血糖值が高值に止つて居るからに因るのである.

（e）糖負荷最終末血糖值の初回注糖前值に対する昇降関係は，注糖時間間隔の如何に拘らず燐家鬼では 負荷終末時に於て極めて著高を持し，健常及び「ア」家鬼共て本検相の時間内では終末低血糖は見られずし て，初回注糖前值より軽度の高血糖走現わしている。

(f) S-E は注糖時間閒隔の如何に拘らず，燐家鬼で著明陰性，健常家鬼で陽性である，只「ア」家乘で 
仿每 2 時間注糖の場合には陽性であるが，毎 1 時間注栯の場合には軽度陰性を星する。

要する亿，注糖時間間隔の如何に拘らず共通的見られる 3 種家鬼に於ける注糖向糖州線上の相違像とし ては，（イ）注糖後の血糖最高峰到達時間の相違，(口)最高峰值の差違，(八)糖負荷終末血糖值の差違，(二) $\mathrm{S}-\mathrm{E}$ の陰陽と其発現程度等が主要なものである，注糖時間の間隔相違てよる特異像としては，注糖間隔铮: 1 時間条件を甲と呼び，其間隔 2 時間条件を乙とせば，甲は乙亿比して其注糖後の終末血糖做が 3 種家鬼何 れ亿於ても高值であつて，殊て燐家鬼では，其注桾時間間隔の相違てよる血糖曲線像の差違が著明である.

又 $\mathrm{S}-\mathrm{E}$ の陰陽発現並びに程度に於ても相違があうて一般に病的の場合には乙よりも甲の場合に其陰性の 程度が著明となるか或は乙の場合に陽性であつたものが甲の場合に陰性化する。

\section{[II 〕 糖負荷後に於ける䁍器, 組織糖質像並びに排泄尿糖量}

（a）糖負荷後伦於ける朋糖質像

正常家鬼では注糖後の朋に於ける総糖質量（游離糖，水解栯及び糖原）の增加は著明で南つて注糖の大部

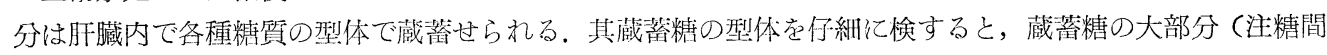
隔每 2 時間の条件で法 $85 \%$ ，1 時間間隔条作では $62 \%$ ) は糖原化せられ，其他の部分は殆ど游離糖として藏 堷せられて居る。燐家鬼で结注糖後の肝亿於ける総糖質量増加は極めて軽微である場合も見られたが其多く は注糖前值よりも減少して居る。「ア」家鬼でも燐家鬼と殆ど同様であるが此場合には初回注糖後には軽增 を証せ弓れて居る，前後雨回注糖後化於ける総糖質量の増減(蓄糖能)を比較すると，次回注糖後に於ける両 種病的家鬼共江其肝蓄楉量妙前回比比して減少を見て居る(表 1 (a), (b).

管 1 表 (a) 糖二重負荷前後の肝糖質像（各 3 例平均值）

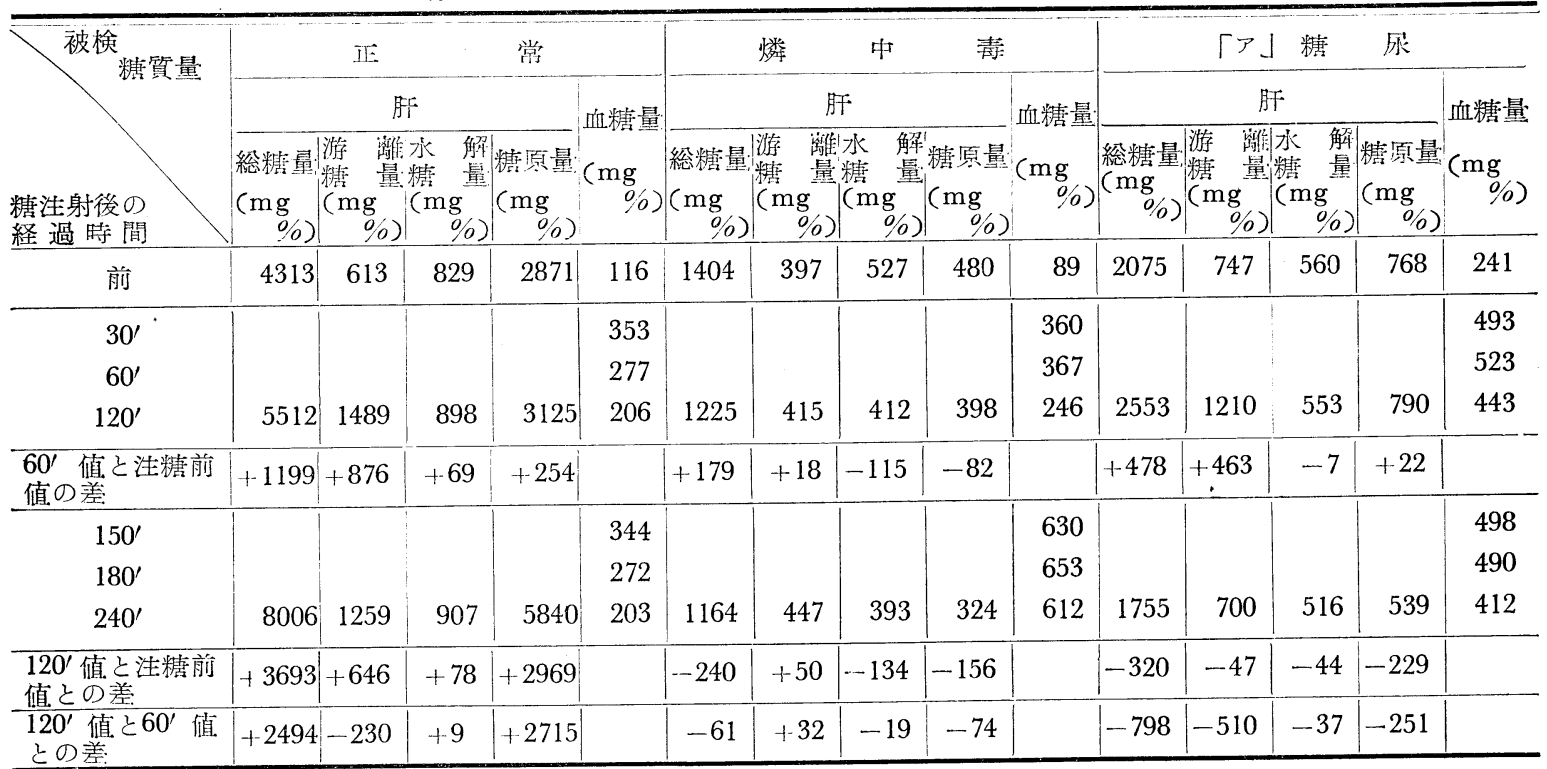

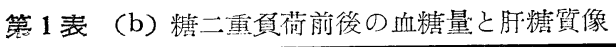

\begin{tabular}{|c|c|c|c|c|c|c|c|c|c|c|c|c|c|c|}
\hline \multirow{3}{*}{$\begin{array}{l}\text { 被検 } \\
\text { 糖貿量 } \\
\text { 糖洼射後の } \\
\text { 経過時閒 }\end{array}$} & \multicolumn{5}{|c|}{ 常 (1 例) } & \multicolumn{5}{|c|}{ 燐中毒 ( 2 例平均值) } & \multicolumn{4}{|c|}{ 「ア」糖尿 (3 例平均值) } \\
\hline & \multicolumn{4}{|c|}{ 肝 } & \multirow{2}{*}{$\begin{array}{l}\text { 血糖量 } \\
(\mathrm{mg} \\
\%)\end{array}$} & \multicolumn{4}{|c|}{ 肝 } & \multirow{2}{*}{$\begin{array}{l}\text { 血糖量 } \\
(\mathrm{mg} \\
\text { \% })\end{array}$} & \multicolumn{3}{|c|}{ 肝 } & \multirow[b]{2}{*}{$\begin{array}{l}\text { 血糖量 } \\
(\mathrm{mg} \\
\%)\end{array}$} \\
\hline & $\begin{array}{l}\text { 総糖量 } \\
(\mathrm{mg} \\
\%\end{array}$ & \% & 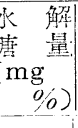 & 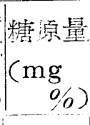 & & 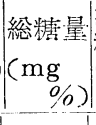 & 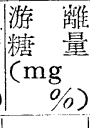 & 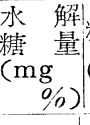 & \begin{tabular}{|c|} 
糖原量 \\
$(\mathrm{mg}$ \\
$\%)$
\end{tabular} & & 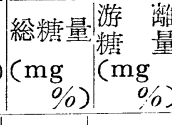 & 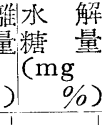 & $\begin{array}{l}\text { 繁糖原量 } \\
(\mathrm{mg} \\
\%)\end{array}$ & \\
\hline 前 & 8000 & 830 & 980 & 6190 & 108 & 578 & 239 & 175 & 164 & 78 & 2027 & 774 & 665 & 365 \\
\hline
\end{tabular}




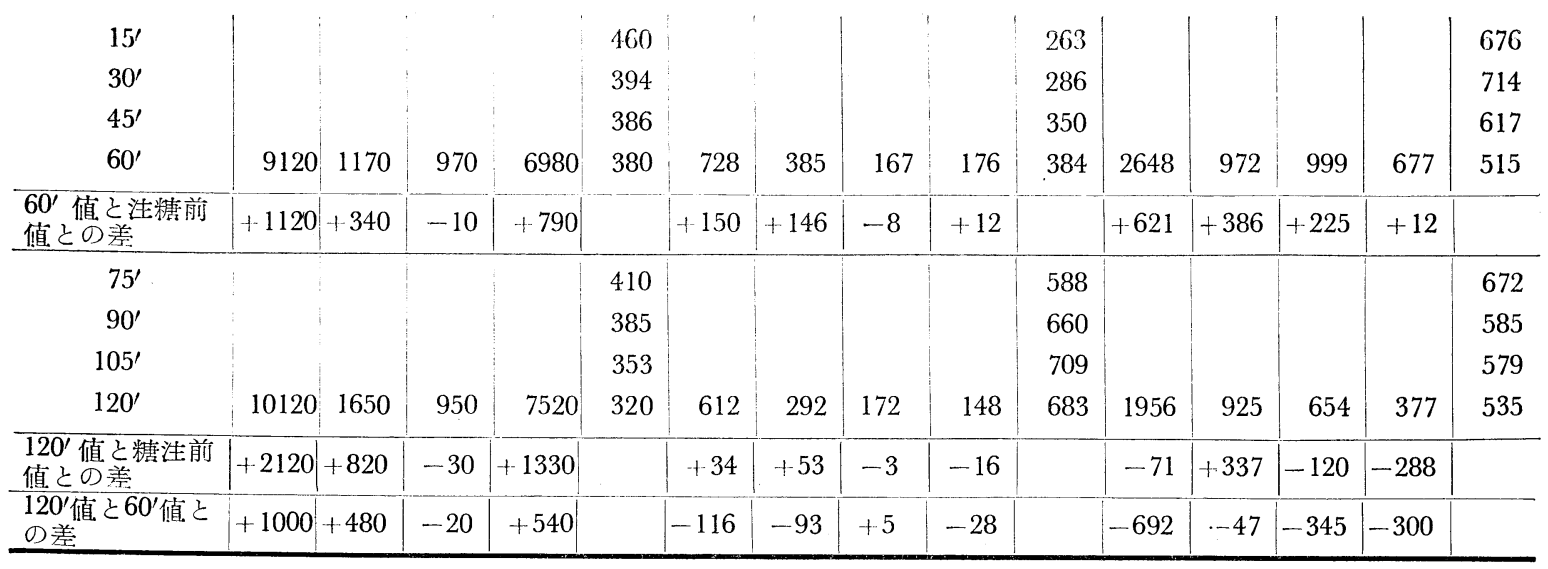

（b）糖負荷後に於ける筋糖質像

健常家鬼では注糖後雨回共に筋総糖質量の増加㕣見られるが，肝に於ける収糖能と此較すると著しく軽微

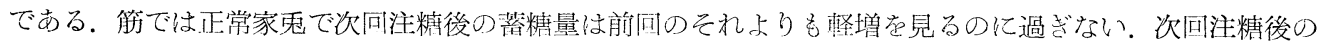

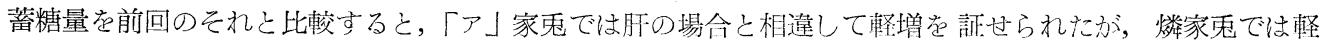
減を見た（表 2 ).

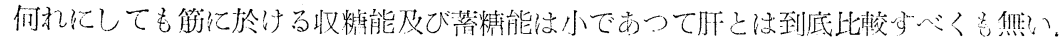

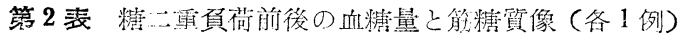

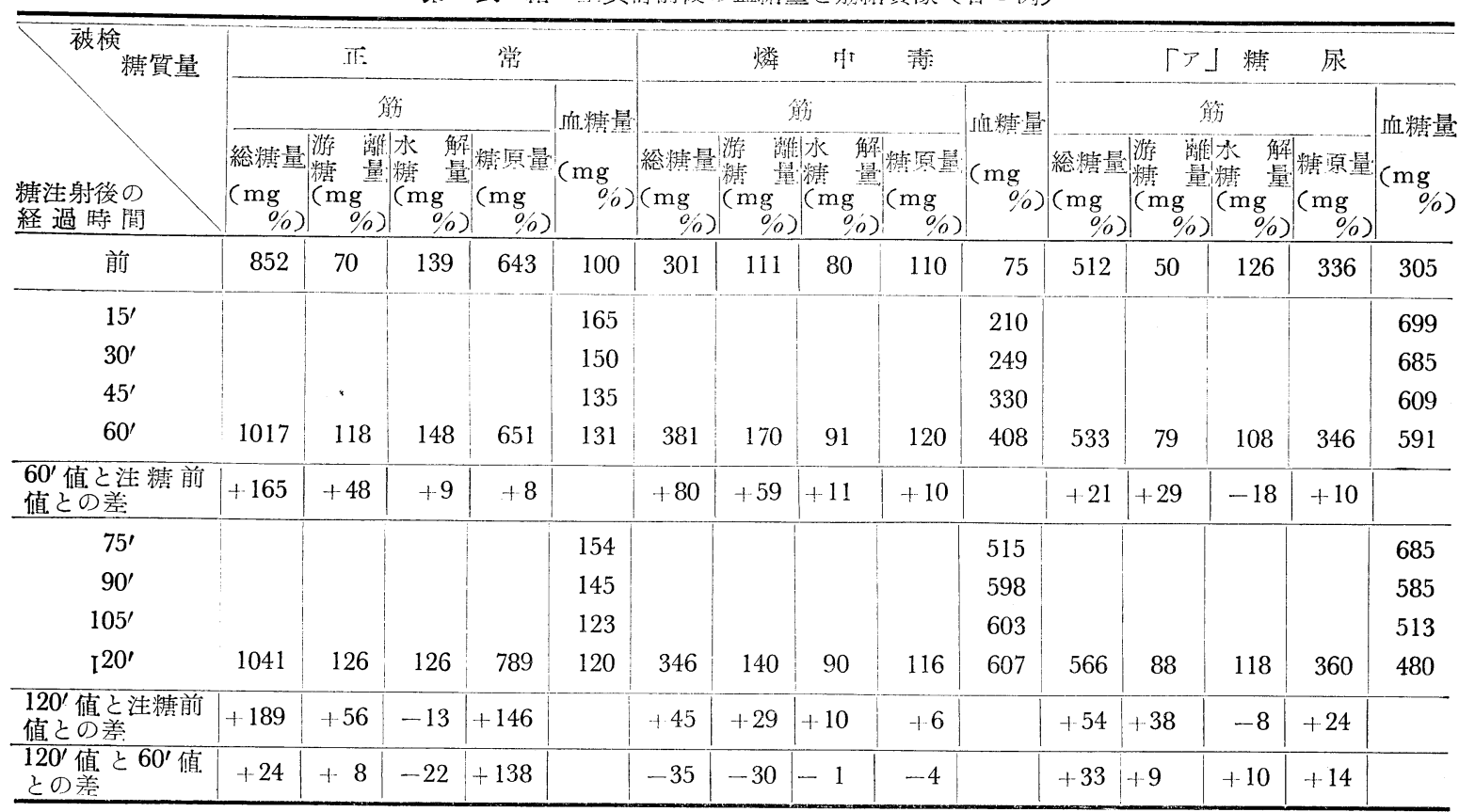

（c）糖負荷後に於ける皮膚糖質像

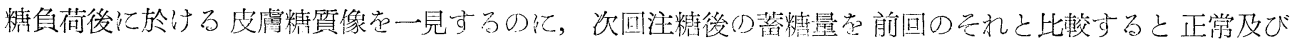

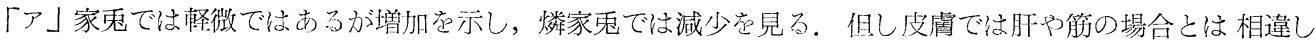

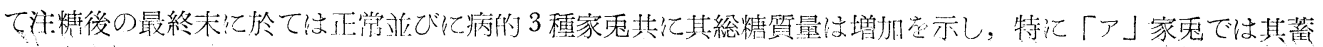


糖量が最大である. 糖原造成能は燐家鬼で全然欠けている（表 3 ).

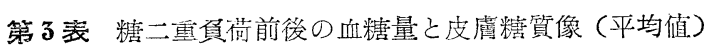

\begin{tabular}{|c|c|c|c|c|c|c|c|c|c|c|c|c|c|c|c|}
\hline \multirow{3}{*}{$\begin{array}{l}\text { 被検 } \\
\text { 糖資量 } \\
\text { 糖注射後の } \\
\text { 経 過 時間 } \\
\end{array}$} & \multicolumn{5}{|c|}{ 正 常 (5 例平均值) } & \multicolumn{5}{|c|}{ 燐 中琴 (3 例平均值) } & \multicolumn{5}{|c|}{$\lceil ア 」$ 糖尿 ( 4 例平均值) } \\
\hline & \multicolumn{2}{|c|}{ 皮 } & & \multirow[b]{2}{*}{$\begin{array}{l}\text { 血糖量 } \\
(\mathrm{mg} \\
(\%)\end{array}$} & \multicolumn{2}{|r|}{ 支 } & & \multirow{2}{*}{$\begin{array}{l}(\mathrm{mg}) \\
\%)\end{array}$} & & 虞 & \multirow{2}{*}{\multicolumn{2}{|c|}{ - 血糖量 }} \\
\hline & $\begin{array}{l}\text { 総糖量 } \\
(\mathrm{mg} \\
0 \% 0)\end{array}$ & 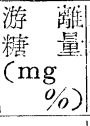 & \begin{tabular}{|cc} 
永 & 解 \\
糖 & 量 \\
$(\mathrm{mg}$ \\
$\%$
\end{tabular} & 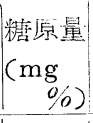 & & 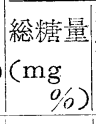 & 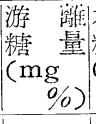 & 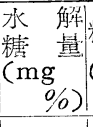 & $\begin{array}{c}\text { 鈢原曐 } \\
(\mathrm{mg} \\
\%)\end{array}$ & & $\begin{array}{c}\left(\begin{array}{c}\text { 総糖量 } \\
(\mathrm{mg} \\
\%)\end{array}\right) \\
\end{array}$ & 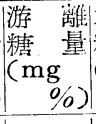 & $\mid \begin{array}{ll}\text { 水 } & \text { 解 } \\
\text { 糖 } & \text { 畚 } \\
\left(\begin{array}{c}(\mathrm{mg} \\
\%\end{array}\right)\end{array}$ & & \\
\hline 前 & 656 & 275 & 213 & 168 & 101 & 480 & 72 & 280 & 128 & 66 & 754 & 319 & 314 & 121 & 368 \\
\hline $15^{\prime}$ & 896 & 431 & 261 & 204 & 363 & 716 & 322 & 288 & 106 & 320 & 903 & 351 & 348 & 204 & 524 \\
\hline $30^{\prime}$ & & & & & 337 & & & & & 331 & & & & & 600 \\
\hline $45^{\prime}$ & & & & & 229 & & & & & 410 & & & & & 567 \\
\hline $60^{\prime}$ & 816 & 324 & 237 & 255 & 214 & 809 & 420 & 291 & 98 & 381 & 1068 & 555 & 295 & 218 & 549 \\
\hline $\begin{array}{l}60^{\prime} \text { 值 と注 糖前 } \\
\text { 值との差 }\end{array}$ & +160 & -49 & +24 & +87 & & +329 & +348 & +11 & -30 & & +314 & +236 & -19 & +97 & \\
\hline $75^{\prime}$ & & & & & 342 & & & & & 529 & & & & & 773 \\
\hline $90^{\prime}$ & & & & & 288 & & & & & 527 & & & & & 655 \\
\hline $105^{\prime}$ & & & & & 268 & & & & & 458 & & & & & 608 \\
\hline $120^{\prime}$ & 828 & 320 & 288 & 220 & 215 & 710 & 331 & 291 & 88 & 409 & 1105 & 605 & 290 & 210 & 566 \\
\hline $\begin{array}{l}120^{\prime} \text { 值と注糖前 } \\
\text { 值と美: }\end{array}$ & +72 & +45 & +75 & +52 & & +230 & +259 & +11 & -40 & & +351 & +286 & -24 & +89 & \\
\hline $\begin{array}{l}120^{\prime} \text { 值 と } 60^{\prime} \text { 值 } \\
\text { との善: }\end{array}$ & +12 & -4 & +51 & -35 & & -99 & -89 & \pm 0 & -10 & & +37 & +50 & -5 & -8 & \\
\hline
\end{tabular}

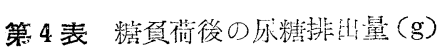
(平均徝)

\begin{tabular}{|c|c|c|c|}
\hline \multicolumn{2}{|c|}{ 注糖間隔時間 } & 2 時闻 & 1 時間 \\
\hline 正: & 常 & 0.64 & 0.48 \\
\hline 燐 中 & 毒 & 1.04 & 0.78 \\
\hline 「ア」粦 & 尿 & 2.24 & 2.51 \\
\hline
\end{tabular}

(d) 糖真荷後伦於ける尿糖排泄量

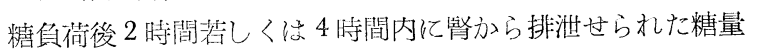
を3 種家鬼で比較した成䋶は表4 亿示す通りである。

左表で見られ名様に燐家鬼では正学家鬼上りも其糖排出量は 大であるし，「ア」家鬼では燐家向上りも2 倍以上大量の糖排

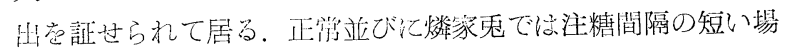
合て其間隔少長い㙋合化比して少量の尿糖排出党見て居るの そ「「ア」家鬼で却つて大量の尿糖排出を見て居る。てれは

「ア」家鬼で注糖間隔が短かつた試獣でた志たま血糖の高い重症なものが多かつた為に因ると思われる。

\section{[III]篖負荷後に於ける贜器, 組織糖質像亚びに排泄尿糖量とS-E との関係}

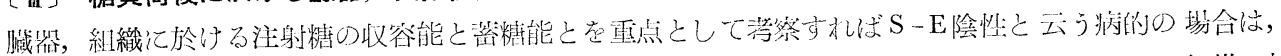

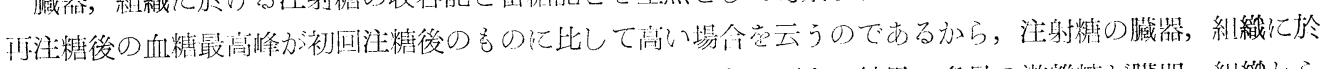

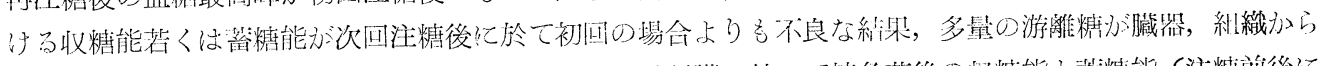

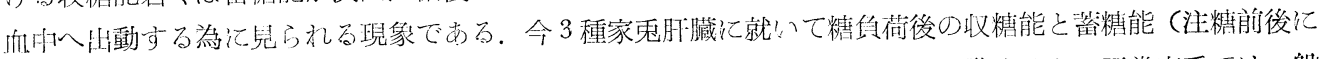

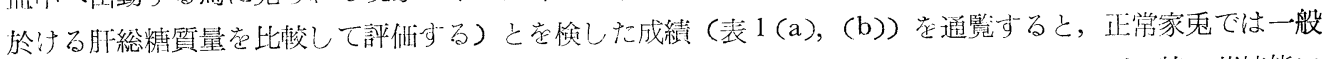

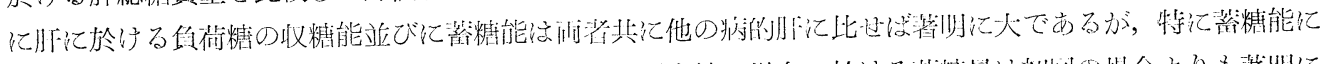

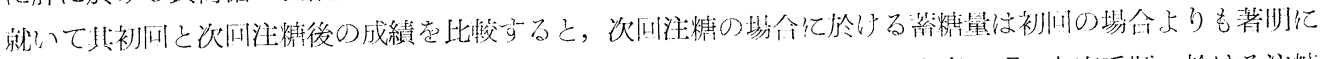

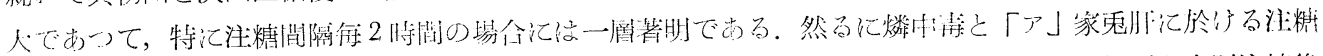

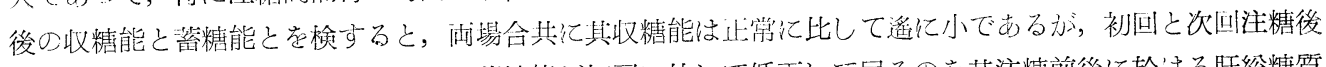

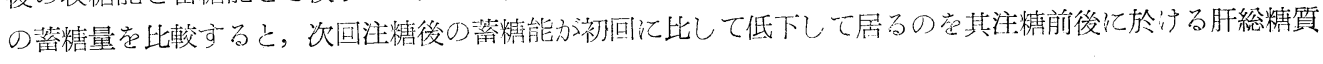
显の比校加推判尔られるのである。 


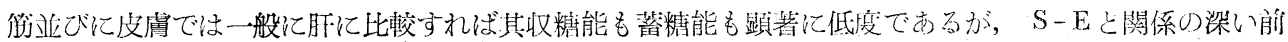

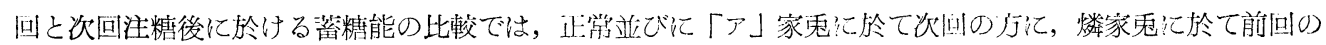
广に蓄桾能力瀀れて居るのを見られた。

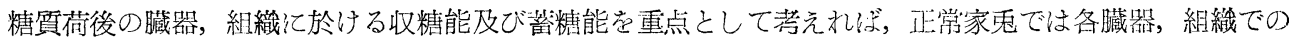
注糖後に於的る収糖能は大であり，且つ蓄糖能は次回注糖後の广が前回の光れよりも遥が大であるから， S - E 陽性である事亿異議仙無く，又燐中毒家鬼では各藏器，組織共に 注糖次回の方方前回に比して其蓄楉 能の低減を見るから $\mathrm{S}-\mathrm{E}$ 陰性であるのは当然である，只「ア」家鬼では其墇糖能の態度を見ると，肝では

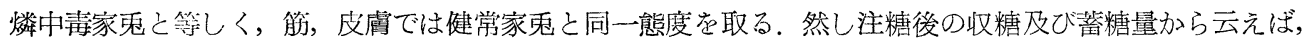
肝に比しては筋や皮膚は軽度汇過ぎない加ら，糖負荷後の収糖及び篦糖能の灭を基準とすれば「ア」家鬼で は其程度は燐家鬼よりは低度であ万うとも，其 S-E蛙性を呈すべく考えて至当と思われる．然るに「ア」 家鬼で织糖負荷曲線で $\mathrm{S}-\mathrm{E}$ は陽性の場合（負荷糖の間隔每 2 時間）と陰性（負荷糖の間隔 1 時間）の湯合

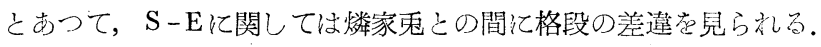

以上糖負荷前後䎲於ける藏器，組織糖質像所見のみを重点として S-E現象の本態を考察するなれば，健

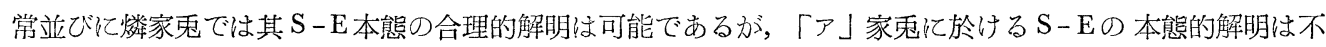

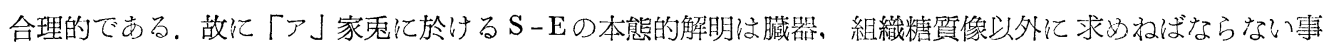
となる.

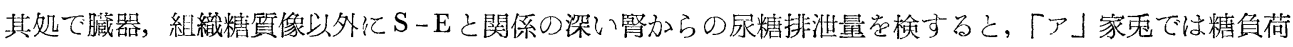
によつて燐家鬼の 2 倍以上の尿糖力渄泄世られて居り，而も大体䎲於て次回注糖後の尿糖排泄量の方力湔回 に比して大である.

朋於ける璃糖能からのみ考えれば，「ア」家鬼では燐家鬼之同等な $\mathrm{S}-\mathrm{E}$ 著明陰性を見らるべき篔である

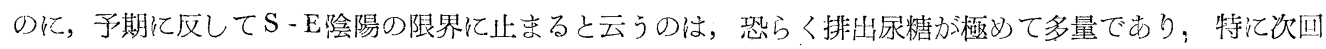
注糖後江前回上り多量の尿糖か排出せられて次回注糖後の血糖上昇度を阻止したと考えられる，尚筋及び皮 膚汇於ける梼負荷後半時の蓄糖能が正常家鬼と同様前回注糖後上りも大であつたと云う点も後半に於ける血 糖上昇度抑制に影響したものと思われる。

次化前回注糖後と次回注糖後们於ける尿桾排出例営摘記すれば下記の如くである.

第 $\mathbf{5}$ 表 糖二重負街試験期間中の燐家兔攻び「ア」家克血, 尿糖量（各 1 例)

\begin{tabular}{|c|c|c|c|c|c|c|c|c|c|c|}
\hline & & 前 $\downarrow$ & $15^{\prime}$ & $30^{\prime}$ & $45^{\prime}$ & $60^{\prime} \downarrow$ & $75^{\prime}$ & $90^{\prime}$ & $105^{\prime}$ & $120^{\prime}$ \\
\hline \multirow{3}{*}{$\begin{array}{l}\text { 燐 } \\
\text { 中 } \\
\text { 毒: }\end{array}$} & 血糖量 $(\mathrm{mg} \%)$ & 70 & 457 & 460 & 570 & 386 & 540 & 626 & 645 & 626 \\
\hline & \multirow[b]{2}{*}{ 疗棓量（g） } & & \multicolumn{4}{|c|}{0.26} & \multicolumn{4}{|c|}{0.53} \\
\hline & & & \multicolumn{8}{|c|}{0.79} \\
\hline \multirow{3}{*}{$\begin{array}{l}\vec{\rho} \\
\text { 精 } \\
\text { 氺 }\end{array}$} & 血粰媓 $\left(\mathrm{mg}^{\circ}, \mathrm{o}\right)$ & 320 & 580 & 597 & 699 & 671 & 705 & 648 & 621 & 592 \\
\hline & \multirow{2}{*}{ 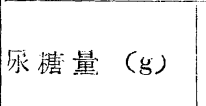 } & & \multicolumn{4}{|c|}{1.00} & \multicolumn{4}{|c|}{1.49} \\
\hline & & & \multicolumn{8}{|c|}{2.49} \\
\hline
\end{tabular}

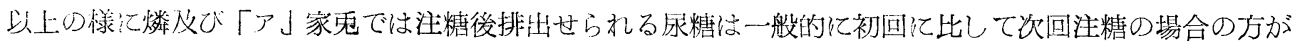

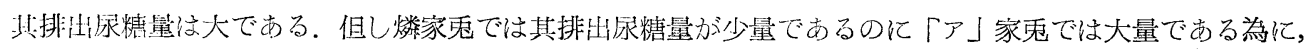

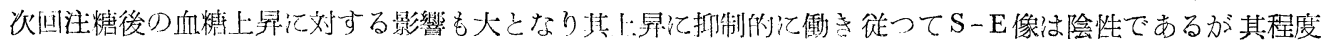
か旉度に止志る結果となつたものと考えられる。

[N] 糖負荷曲線上に於けるS-Eの本態的考察

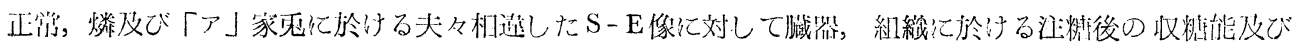


蓄糖能の検較並びに注糖後の尿糖排泄関係等を照応した後糖負荷曲線て於ける $\mathrm{S}-\mathrm{E}$ の本態学考察して見よ j.

(a) 肝に於ける収糖能

肝に於ける次回注糖後の収糖能が前回の場合よりも不良なれば S-Eが陰性を呈すべきですると理論的に 考えて差支は無いと思われる，然る亿上記の実駼結果加ら 3 種家鬼に於ける収糖能は正常，「ア」，燐家鬼の 順位で特に正常の場合の収糖能は著明に強大であるが，前後両回注糖の場合に其何れの方に於て其収糖能力ジ 大であつたが，上記の実験のみでは判然とせない，只注糖後の肝総糖質量変化と注糖後の血糖曲線推移 (燐家鬼で法注糖後の血糖最高峰は正常若くは「ア」家鬼とは相違して注糖後30分以後である)と加ら推して, 燐家鬼で驻収糖能よりも蓄糖能の方がより不良であり, 其結果として S-E強度陰性を呈したと考えられる。 故注糖後の肝収糖能は S-E 左右する条件の一亿は相違無いが $\mathrm{S}-\mathrm{E}$ 像の上に差程密接な関係を持たない と考えられる。

(b) 肝蓄糖能

注糖前後に於ける肝総糖質量の差を以つて肝蓄糖能を評価したものとすれば，正常と燐家鬼との間には蓄 糖能上顕著な差違のある事を知られる許りで無く，特て次回注糖後の蓄糖能か湔回のそれ亿比し燐家鬼では

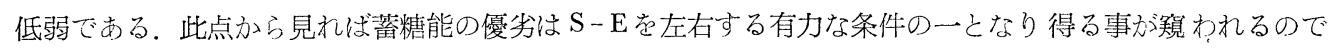
ある.

然るに「ア」家鬼では肝蓄糖能と S-E像とが相並行せず，肝蓄糖能の顕著不良にも拘らず， $\mathrm{S}-\mathrm{E}$ 像は陰

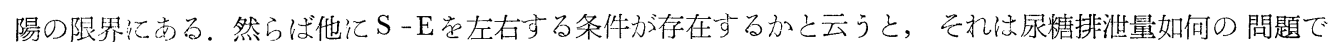
ある。

(c) 糖負荷後の尿糖排泄量

注糖後の肝蓄糖能のみから云えば「ア」家鬼では燐家鬼之同程度な S-E 陰性像を呈ずべ代拘らず，そ れが陰陽の限界に止まると云うのは，燐家黾化比して「ア」家鬼では尿糖排泄が 2 倍以上も大であり，特に 次回注糖後の尿糖排泄が多量であるか⿰力口, 其結果として次回注糖後の血糖上昇度が阻止せられ, 従つて $\mathrm{S}$ $\mathrm{E}$ 像か陰陽の境界に止つたと解釈せられる。此点から注糖後の尿糖排泄量も $\mathrm{S}-\mathrm{E}$ の上にある程度の影響を 及したと看て差支無いと信ぜられる。

尚「ア」家鬼では筋，皮膚亿於ける注楉後の蓄糖能が正常家鬼之同程度であつて，次回注糖後の蓄糖量が 前回のそれより大であつたから，此点も「ア」家鬼の糖負荷曲線上そ於ける S-E像上亿影響を及ばした之 看られる.

要するに糖負荷血糖曲線上亿於ける S-Eの本態としては先ず第一亿注糖後の游離糖の肝篦糖能如何が密 接な関係を有し, 第一汇注糖後の尿糖排泄量力関係党有し, 第三注糖後の肝收糖能如何と筋, 皮膚々於引 る蓄糖能とか関係有すると考えられる。

\section{IV. 総括}

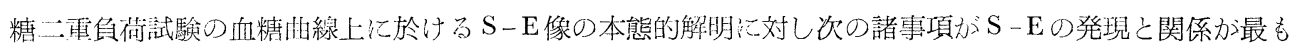
深いと洘えられた。即ち(a)藏器, 組織汇於ける注射糖の収容並びに蓄糖量を知り, 初回と次回注射後に於

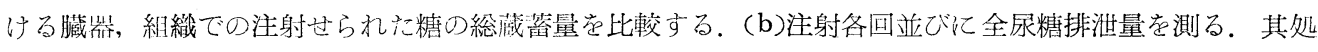
で著者统注射後の $\mathrm{S}-\mathrm{E}$ 像上で夫々相違した態度觉示す正常 ( $\mathrm{S}-\mathrm{E}$ 陽性), 燐中毒 ( $\mathrm{S}-\mathrm{E}$ 強陰性) 及びア口 キサン ( S - E 陰陽不定) 家鬼々就いて, 注糖後の藏器, 組織て於ける収糖能子蓄糖能の比較並びに注糖後 各回及じ全尿糖排泄量莸測つて次の成䋶党得た。

(1)糖負荷後の血糖曲線上: 3 種家鬼の間に夫々の特徽定見られた。

(A) 注糖時間の間隔如何门拘らず 3 種家鬼間亿見られる特異像としてね

(a) 注糖後の血楉最高峰到達時間亿 3 種家鬼夫久亿相違堂見られる.

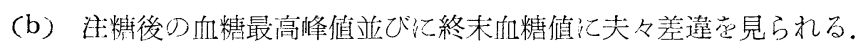


（c） S-E 像上に夫々特異な差違を見られる。

(B) 注糖時間の間䧣相違による特異像としては

(a) 注糖間隔每 1 時間の条件(甲)では毎 2 時間条件家鬼(乙)に比して, 注糖後の 終末血糖值が 3 種家鬼 共通に高く，特に燐家鬼では著高を見る。

（b） S-E の陰陽発現及び其程度にも相違を見，燐家鬼では乙よりも甲家鬼で其陰性の程度が著明となり， 「ア」家鬼では大体上甲家鬼で陰性，乙家鬼で陽性となる。

(2) 注糖後の肝に於ける収糖能及び蓄糖能（注糖前と注糖後一定時間に於ける肝総糖質量の増減度を以つ て評価するつは，正常家鬼では病的肝に比して著明に大であつて，特沉次回注糖後の蓄桾量は初回のそれよ りも顕著に大であるが，燐及び「ア」家鬼で法次回注糖後の蓄糖量低減が著明である。

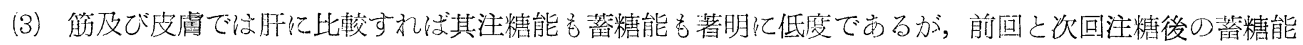

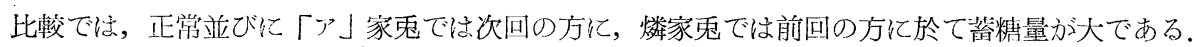

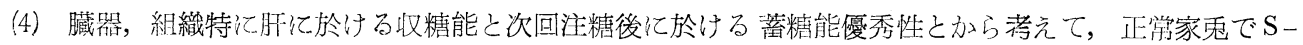
$\mathrm{E}$ の陽性で而るのは当然であるが，又注楉後の肝総糖量変化と血糖曲線の推移と加ら推して，燐家鬼に於

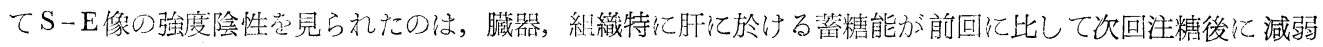
与尚加らに因当之洘えられる。

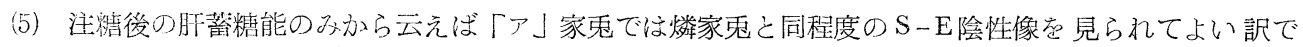

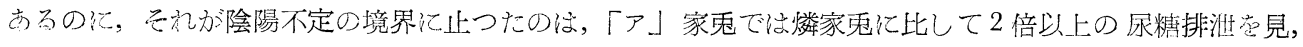
特て次回注糖後の尿糖排泄が多量である為に，其結果として次回注糖後の血糖上昇度が阻止せられ，䣊ア」

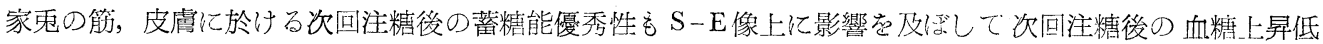
下作用し，此両作用によつて S-E像の陰性度が隇ぜられたもの之解せられる，

（6）以上 3 程家鬼亿於ける注糖後の藏器，組織糖質像並びに尿糖排泄所見汃ら，糖二重負荇血糖山線上に 見られる $\mathrm{S}-\mathrm{E}$ 像の本態として先ず第一に $\mathrm{S}-\mathrm{E}$ 像と最も密接な関係があると認められるのは，次回注糖後の

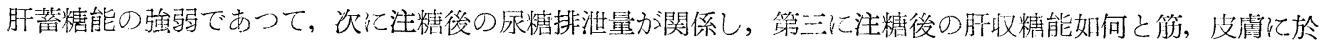
ける蓄糖能如何とが関係学有するものと思礼当。

(本論文の褧旨は第27回日本两分泌学会(炤和 29 年 4 月)席上で報告した).

\section{参 考 文 献}

1) Hamman \& Hirshman: Johns Hopk. Hosp. Bull. 30, 306, 1919 $118,93,1921$ 104, 587, 1926
3) Traugott : Klin. Wochenschr. 1, 892, 1922 5) Depisch \& Hasenöhrl: Klin. Wochenschr. 43, 2011, 1926
2) Staub: Biochem. Zeitschr. 4) Staub : Zeitschr. Klin. Med. Hasenöhrl: Zeitschr. gesamt. exp. Med. 58, 81, 1928

7) Adlersberg \& Porges: Klin. Wochenschr. 32, 1451, 1926 8) Nieisen \& Lewis: Arch. Path. \&

Lab. Med. 3, 212, 1927 9) Jordan : Am. Journ. Physiol. 80, 441, 1927 10) Kohn, Fries \& Felshin: Am. Journ. Dis. Child. 34, 857, 1927 11) Deuel \& Gulick: Journ. Biol. Chem. 89, 93, 1930 12) Holt \& Greisheimer: Proc. Soc. Exp. Biol. \& Med. 28, 547, 1931 Arch. Int. Med. 50, 8011932 13) Cori : Physiol. Rev. 11, 197, 1931 14) Williams \& Dick: 15) Soskin, Allweiss \& Cohn: Am. Journ. Physiol. 109, 155, 1934 16) Soskin \& Allweiss: Am. Journ. Physiol. 110, 4, 1934 Int. Med. 56, 927, 1935 18) Soskin \& Mirsky: Am. Journ. Physiol. 112, 649, 1935

19) Soskin, Mirsky, Zimmerman \& Heller: Am. Journ. Physiol. 114, 648, 1936 20) Soskin, Essex, Herrick \& Mann: Am. Journ. Physiol. 124, 558, 1938 21）沢田：日内会誌，20，407，1932

22) 沢出: Journ. Biochem. 17, 91, 1933 23) 乘金: 景府医大誌, 37, 783, 1943 24) 新海 : 果京医会誌，56，747，1942 25) 中野: 生化学, 25, 199, 1953 26) Hagedorn \& Jensen :

Biochem. Zeitschr. 135, 46, 1923 小医化学実習 (献江掌) 206，1941

27) 山本: Journ. Biochem. 32, 389, 1940 28) 須藤 :

29) 高田(八)：火阪医会誌，37，433，1938 